\title{
Creativity in Everyday Literacy Practices: The contribution of an ethnographic approach
}

\author{
KARIN TUSTING and UTA PAPEN
}

\begin{abstract}
In this article we explore creativity in everyday literacies. We argue that much creativity can be found in the seemingly mundane and repetitive acts of text production and text use that are part of everyday life and work. Such creativity can only be identified, however, if we look beyond the texts themselves and examine the practices of making and engaging with texts. Once we leave aside conventional text-based notions of creativity, which focus on aesthetic features of language, we can understand creativity as a 'popular' and 'ubiquitous' event. To support our argument, we give examples from two different contexts: research on literacy in a parish community in the North-West of England and a study of literacy in relation to community-based tourism in Namibia.
\end{abstract}

\section{Literacy and creativity}

Literacy studies has long challenged previously dominant notions of literacy as a decontextualised skill (Street 1984, Barton 2007). Studies of literacy practices in context have shown clearly that people produce, use and generally interact with texts in different ways in different social contexts. These practices are patterned by social structures, institutions and power relationships. They are purposeful and part of people's broader social goals. They are shaped by the cultural practices within which they are situated, locally and historically. And such practices hold intrinsic meanings for the people involved, which vary according to the personal, social and cultural context (Barton and Hamilton 2000, Papen 2005).

To date, much of the focus of work in literacy studies has been on researching such practices in different contexts, describing the range of activities and meanings involved and relating the local literacy practices to the broader social context, challenging 'autonomous' notions of literacy (see for example Street 1993, 2001, Barton and Hamilton 2000). Creativity is not a concept that has so far enjoyed a great deal of focus in this work. Now that the socially situated nature of literacy practices has been established, it is of value to explore in more depth what this means for various aspects of our understandings of text in people's lives. 
This article explores creativity in everyday literacy practices. We have already explained that literacy practices are socially situated, and need to be understood in relation to their social contexts. However, this does not imply that they are socially determined. There is a great deal of creativity in the way people respond to the potentials and limitations of different social contexts, to produce and interact with written texts. As we have argued previously (Papen and Tusting 2006), by exploring practices involved in text production, we can see that there is creativity even in seemingly routine or mundane literacy practices. We will give examples of this creativity from our own research, and explain how this can be understood in relation to the social practices and the social and cultural context in which the literacyrelated activities are situated.

\section{Understandings of creativity}

There are many ways of being creative with written language. Only some of these, however, tend to be identified as important or legitimate forms of creativity. Banaji and Burn (2007:62) suggest that the notion of 'creativity' is 'constructed as a series of rhetorical claims', and then go on to identify several rhetorics of creativity associated with different philosophical or political traditions. The first, 'Creative Genius', argues that creativity is a 'special' quality, associated with highly educated and talented individuals, and elite artistic and cultural products. This notion remains implicitly the dominant one in much of the discourse around creativity. It is close to what Craft (2001) calls 'high' creativity: the creation of something remarkable, new and original, unlike anything that has been made before. Such a creative product changes our perspective on the world. This position is challenged by the rhetoric that Banaji and Burn term 'Democratic Creativity', which shares the position that creativity is associated with artfulness, but highlights the existence of similar 'creative' aesthetic features in popular cultural products and patterns of cultural consumption.

Much research into creativity in language shares the focus on aesthetics of both 'Creative Genius' and 'Democratic Creativity'. Academic studies of creativity often focus on aspects of language use that foreground Jakobson's 'poetic' function (Jakobson 1960); that is, language that draws attention to its own form, through features such as parallelisms, repetition, rhyme and other sorts of 'word play' (Cook 2000, Carter 2004, and see Maybin and Swann 2007). This conceptualisation of creativity in relation to aesthetic and poetic features of language tends to lead to a position where texts can be categorised as being 'more' or 'less' creative.

Our position, and, we argue, the position implied by the theoretical stance of seeing literacy as social practices, is encapsulated by the rhetoric Banaji and Burn label 'Ubiquitous Creativity'. This suggests that creativity is inherent and essential in people's everyday lives, a position that resonates 
with Kress' work on writing and multimodality (Kress 2003). He suggests that sign-making of any kind is always producing a new sign, even in the case of one that is made in response to, and as an interpretation of, a sign that already exists. From this perspective, creativity does not necessarily have to refer to making something startlingly original, apt, witty or playful, but can simply mean the human capacity for making meaning in a situation where no communication existed before.

Kress shows that, even where a text might not appear creative in itself, the production of texts is never just a process of copying and repetition. Rather, the sign-maker selects and combines the means and modes available to them to make meanings, a process that always entails adaptation and change. Levi-Strauss (1972) has described this process as 'bricolage' (literally, making do by putting together whatever is at hand). The bricoleur is someone who makes use of means that are already there, but which have not necessarily been conceived for the purposes the bricoleur has in mind (see also Derrida 1978, Robins 1996). Creativity lies in the bricoleurs' ability to capture or imagine the potential of the things they find in their environment. As the mundanity of the term 'bricolage' suggests, from this perspective creativity is seen not as the privilege of the particularly gifted, but as a common, everyday occurrence.

Our analysis of creativity therefore does not focus merely on the creative elements that can be identified in texts. Instead, we examine texts as part of a broader process of researching the everyday literacy practices through which people in a range of different settings produce and interact with texts. As Pahl (2007) has shown with regard to children, a focus on literacy events and literacy practices - the units of analysis drawn on by the New Literacy Studies - makes it possible to draw out the creativity inherent in texts which might appear as texts to be less than creative, if examined only in themselves. We take a similar approach. Looking at how people produce and use texts, we identify the creativity inherent in seemingly mundane forms of written communication, even where the texts themselves might show little evidence of the language features normally associated with 'artfulness'. Rather than exploring language features and categorising texts in terms of their relative creativity, we will argue that text production practices are intrinsically creative. Furthermore, we argue that it is necessary to study text production and text use in their local settings to understand how these creative processes are shaped by the potentials and limitations of different social contexts. We illustrate this argument using examples taken from ethnographic literacy research.

\section{Studying literacy and creativity: ethnographic methods}

If, as we have suggested above, creativity can be found in everyday acts of producing and using texts, we need to find ways of studying these 
activities that allow us to draw out their creative aspects. Crucially, this requires methods that go beyond only examining texts as such (for example discourse analysis or literary criticism). Instead, we need an approach that also allows the researcher to understand the social activities involving the use and production of texts. We need to find out about people's intentions in dealing with and producing texts. And we need to gain a thorough understanding of the broader social, cultural and economic context within which the acts of text making and text use take place. Only then can the creativity inherent in what people do with texts become visible.

Ethnographic methods - detailed observations of and participation in social practices over time - allow us to study literacy practices in this way. Hamilton (1999) describes ethnography as traditionally having four characteristics: researching real-world settings; aiming for holistic descriptions of a culture, on the basis of years of immersion in that setting; being multi-method, using a variety of research techniques to generate a range of types of data; and aiming to represent participants' own perspectives, otherwise called an interpretative approach. As Hamilton suggests, research of the kind we draw on in this article is better described as taking an ethnographic 'approach' or 'stance'. The research we describe here does not aim to describe an entire culture after a period of immersion of several years. However, it does focus on studying practices involving texts in real-world settings, using multiple methods to generate holistic, interpretative descriptions of literacy practices, set in their broader social context.

The aim of an ethnographic approach to researching literacy practices is therefore to use a multi-method approach to systematically record and describe any literacy-related activities in the context of the social practices of which they are part. In a further step, these descriptions have to be analysed in order to identify their patterns and the relationships between them (see Barton and Hamilton 1998, Tusting and Barton 2005). This requires the ethnographer to observe and participate in literacy events, and to talk with the people involved. Interviews - usually unstructured or semistructured - aim to gauge people's intentions and attitudes, their understanding of the situation in question and their own views in relation to what they are doing.

In the following sections, we will demonstrate how this ethnographic approach to studying literacy practices reveals the creativity inherent in these practices. It enables us to describe in detail the process of selecting and combining meaning-making strategies described above, showing how people draw on the semiotic resources available to them in creative ways to fulfil the demands of particular situations. We will show this process in relation to literacy practices from two very different contexts: people publishing a weekly church bulletin in a Catholic parish in the North-West of England, 
researched by Tusting, and people producing advertising texts in Namibia, researched by Papen. Neither of these studies originally focused primarily on creativity, but re-examination of the data from this perspective draws out the creativity inherent in both. These examples will demonstrate how the creativity inherent in people's everyday literacy practices is socially shaped: how it involves adaptation to social and institutional constraints, how it is drawn out and bounded by the potentials and limitations of different contexts, and how new and hybrid discourses call forth creativity in literacy practices.

\section{Recurrent creativity: the production of a weekly parish bulletin}

Our first example comes from research carried out in a Catholic parish, which explored the roles of written texts in the construction of community identity (Tusting 2000a, b). Data were collected through eighteen months of participant-observation in parish life. This entailed attending as full a range as possible of parish groups and activities on a regular basis, having informal discussions with parish members and recording detailed descriptive field notes that focused particularly on communicative practices involving texts. These field notes formed the principal dataset analysed for the project. Parishioners were aware of Tusting's role as a researcher and of her area of research interest throughout.

One key text in the parish was the weekly bulletin, which contained news and information about that week's events. The bulletin consisted of a piece of A4 paper, printed on both sides and folded into a four-page booklet (see Figure 1, below). It was given out to each person attending Mass at any of the churches in the parish. A sample copy of each bulletin was collected each week over 10 months.

The example in Figure 1 shows the general form of the bulletin. It is made up of a number of distinct sections, each demarcated by a short title. The overall structure and format is similar in each issue. The content is diverse, covering in a single sheet a wide variety of topics relating to several domains of experience: spiritual, administrative and bureaucratic.

Interpersonally, the bulletin serves various functions: providing information, inviting attendance, requesting actions, thanking and questioning. Different audiences are addressed: some sections address the parish as a whole, but most are for particular groups, such as those who wish to have their child baptised, young people, parents of children attending parish schools, or people who supported various events, with some of the prayers directly addressing God or the Holy Spirit. Discrete sections occupy distinct spaces with few links constructing coherence between them, different fonts and 
graphics are used, and there is little linguistic cohesion between the different sections.

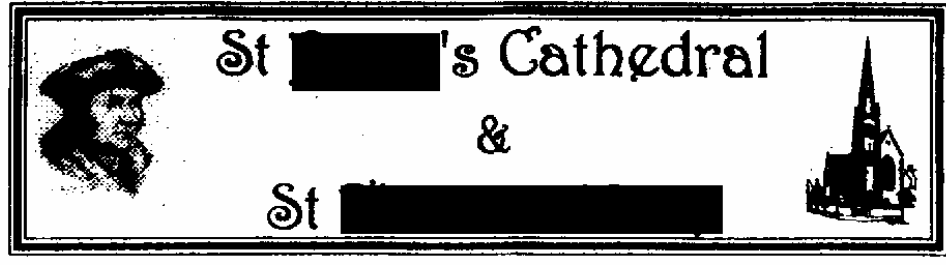

3RD SUNDAY IN ORDINARY TIME (YEARC)

THE CATHEDRAL

Sunday Masses

Vigil: Saturday $6.30 \mathrm{pm}$

Sunday: $10.30 \mathrm{am} \& 6.30 \mathrm{pm}$

Children's Liturgy: 10.30am

Weekdar Mass : $12.05 \mathrm{pm}$

Monday - Saturday

in the Convent Chapel

\section{Confessions}

Saturdays: $\quad \begin{array}{ll}11.00 \mathrm{am} & -12 \text { noon } \\ & 4.00 \mathrm{pm}-5.00 \mathrm{pm}\end{array}$

Exposition of the Blessed Sacrament

Saturday $9.30 \mathrm{am}-12$ noon.

\section{ST}

Sunday Masses

Vigil: Saturday $6.30 \mathrm{pm}$

Sunday: $9.15 \mathrm{am}$

Weekday Mass

Monday - Friday $9.00 \mathrm{am}$

\section{Confessions}

Saturday: $6.00 \mathrm{pm}-6.20 \mathrm{pm}$

$$
\begin{aligned}
& \text { HOUSE } \\
& \text { Sunday Evening Prayer and } \\
& \text { Benediction at 4.30pm }
\end{aligned}
$$

\section{TODAY'S READINGS}

Nehemiah 8:2-6.8-10; Psalm I8; 1Corinthians 12:12-30; Luke1: 1-4;4:14-21

\section{THOUGHT FOR TODAY}

CHRIST IS PRESENT IN HIS WORO

The Word challenges us to a renewal of life. As the people rediscovered their identity when Ezra read the Word to them, those who read the Word of God in the Scriptures will finds the joy of the Lord to be their strength.

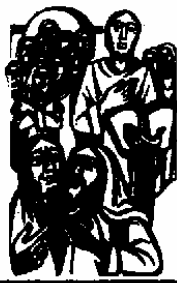

\section{TH JANUARY 1998}

TEL:

Roman Catholic Diocesan Trustees Registered - Registered Chariby No.

Figure 1: A sample parish bulletin 


\section{PARISH QUESTIONNAIRE}

At all Masses this weekend you are invited to complete a questionnaire prepared by members of the parish Council, asking for your opinions which will help in planning the future of our parish. Copies will be available during the week and next weekend for anyone unable to complete it this weekend.

\section{CHRISTIAN UNITY}

There will be a Unity Service today, Sunday, 25th, at $4 \mathrm{pm}$ in Christ Church for parishioners of the

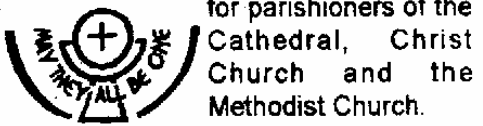

SPUC WHITE FLOWER APPEAL

Thank you to all who gave so generously to SPUC in the White Flower Appeal last weekend.

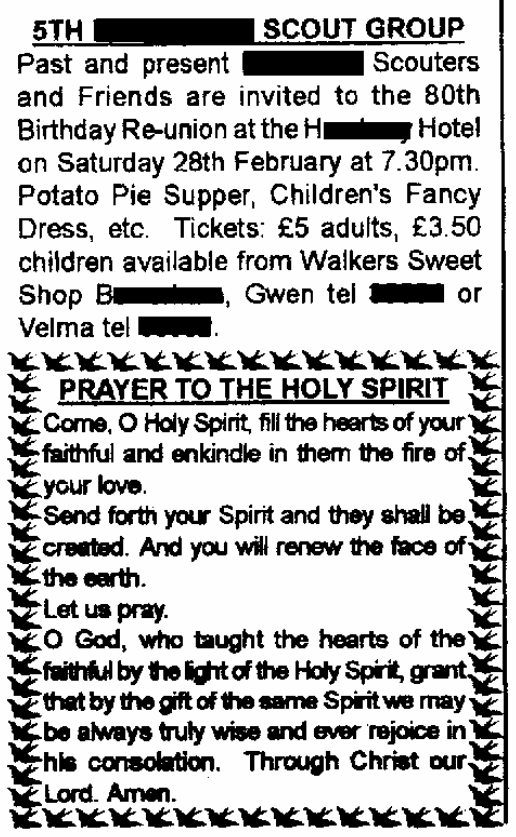

\section{CAN YOU HELP?}

The clergy in Cathedral House are looking for someone to cook a simple, straightforward meal from Tuesday Friday inclusive. Anyone interested please contact any of the clergy.

\section{BAPTISM COURSE}

Today at 3.00pm for all those who wish to have their child baptised within the next 6 months.

\section{MUSIC GROUP}

There will be a practice in the Conference Room on Thursday 29th January at $7.00 \mathrm{pm}$. All newcomers welcome. Please enter via the Cathedral porch.

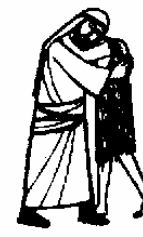

PREPARATION FOR

\section{RECONCILIATION}

We welcome the children and their families to the $9.15 \mathrm{am}$ and $10.30 \mathrm{am}$ Masses today.

The children will receive the Sacrament of Reconciliation for the first time next Friday, 30th January at $6.30 \mathrm{pm}$ in the Cathedral. There will be a short practice on Wednesday at $6.30 \mathrm{pm}$ in the Cathedral. We ask the prayers of all parishioners for the children and their parents at this time.

\section{CATHEDRAL LINK}

The Editor would be very grateful for any items/articles for the February edition of the Cathedral Link - especially any reports from parish groups. Please leave at Cathedral House before next Sunday.

\section{THANK YOU}

To all those who supported the recent Bring and Buy Sale at St which raieed $\mathbf{2 5 0}$ in aid of the Blue Peter Appeal. 
FEASTS THIS WEEK

Tueodey 27th: St Angela Merici Founder of the Ursulines, devoted herself to Christian education based on love, kindness with firmness and concern for the individual.

Wednesday 28th: St Thomas Aquinas $\mathrm{He}$ is the patron of schools and Universities. A great theologian of the Church who taught that Christian revelation and human knowledge are aspects of a single truth and cannot be in conflict with one another.

Saturday 31st: St John Bosco: Founder of the Salesians to educate boys for life. He believed in giving himself to others first in order to give God tc them.

\section{WORLD LEPROSY DAY}

Is celebrated today and we ask you to remember in your prayers all those work in this field to receive suffering.

\section{POPES PRAYER INTENTIONS FOR FEBRUARY}

That greater importance may be attached to the sacrament of Confirmation in catechesis and in the life of the Church; and that young Christian communities may find qualified and suitable educators for the seminaries and centres of higher education.

CONFIRMATION AND VOCATION John XXIII tells us that early as possible parents should begin to tell children of their duty to help Jesus with his work of bringing the Good News to all people and building up his Kingdom and to point out that each will have his/her own unique opportunities and ways of doing this. As children grow this elementary concept of personal vocation should be developed.

\section{THANK YOU}

for two donations received during the week: one of $£ 50$ and the other of $£ 74$.
CATHEDRAL PRIMARY SCHOOL The reports of the recent Otsted and R.E. Inspections has now been published and copies available from the school. The school received a glowing report which praised The Cathedral as "a good Catholic school" as well as highlighting the good and very good teaching which takes place in the majority of lessons and the good quality of behaviour and relationships between all at the school. The staff, pupils parents and governors have every right to be proud of the school and are delighted with the report.

HIGH SCHOOL

The Sixth Form Options Evening will take place at

$$
\text { High School }
$$

on Thursday 29 th January

from 7.00pm - 9.00pm.

\section{EASTER RETREAT FOR YOUNG PEOPLE}

Years 11 upwards, cost £45.

Come and join the residential team of $\mathrm{C}$ a difference. For further details contact: The Booking Officer, C Manor, $\mathrm{K} \longrightarrow \mathrm{Te}$ :

UPON MY WORD
We live surrounded by words. Our waking
hours are flooded with torrents of endiess
talk. Newspapers teem with words
describing people, events and places.
While familiarity can breed contempt, over
farnilianty with the Word of God, can lead
to indifierence or apathy.
Wo need to develop a warm and living love
of Scripture. Perhaps bringing the Sunday
Readings home with us for later reading, or
using a good commentary to guide us.
Taking a couree, or joining a study group.
Like poetry, the only woy to get to know
Scriphure is to read, reed agein end then




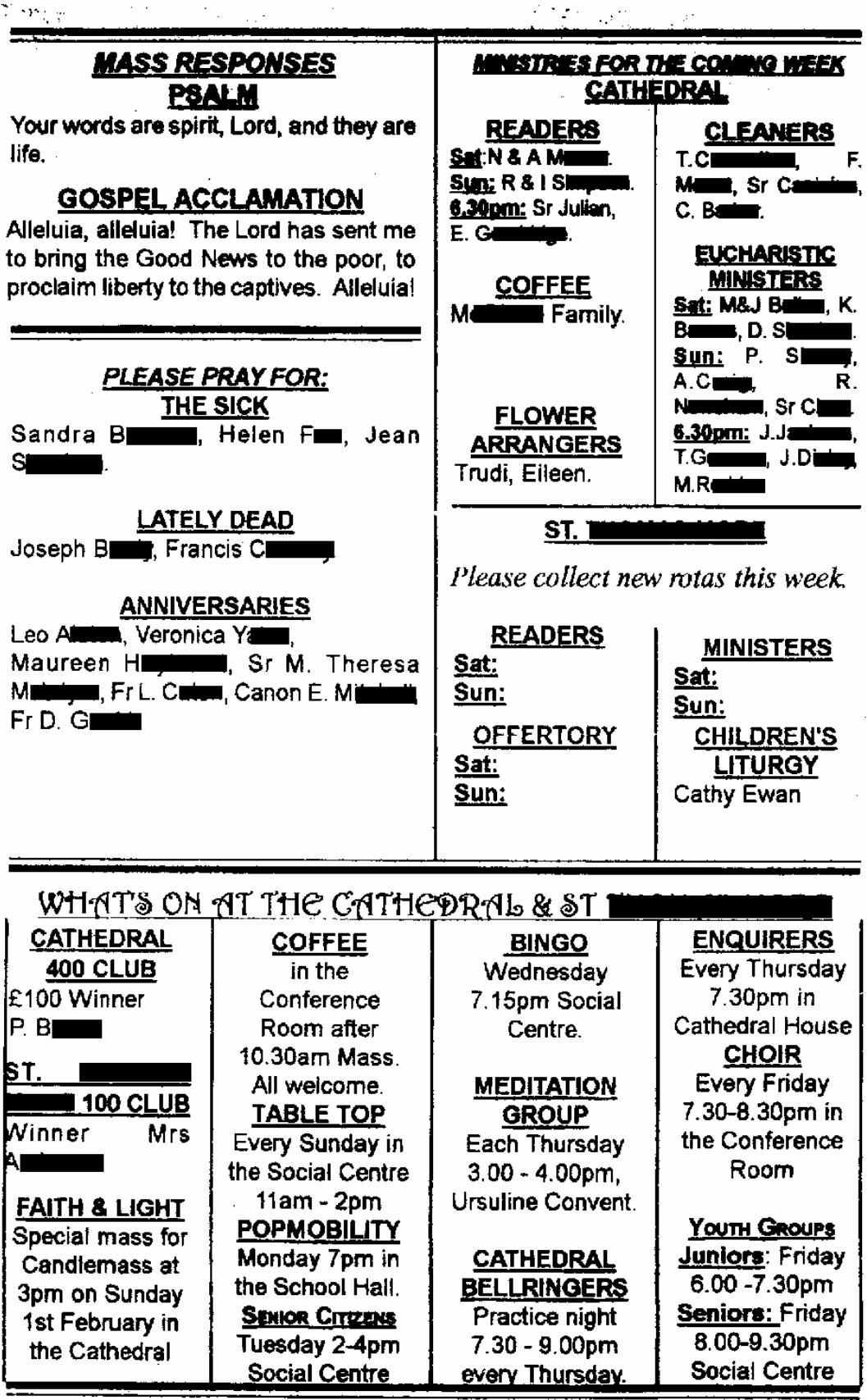

A rhetoric of creativity focusing on unusual or artful aesthetic features might dismiss the parish bulletin as a mundane administrative piece. However, analysis of the practices by means of which the text was produced shows the creativity involved as the bulletin producer engaged in a complex 
process of selection and combination to meet a wide range of demands in the production of this heterogeneous text.

Each week, the bulletin was produced on a Thursday morning by the parish secretary, who was interviewed in detail regarding this process. She also worked in the church office part-time doing administrative work, as well as being involved in much of parish life, and was therefore one of the few people who was aware of most of what was going on, in a very active church community with many different groups and activities.

The information drawn on to produce the bulletin came from very many different sources. Parish groups left notes and messages at varying levels of detail in the 'bulletin box' in the parish office. The parish diary listed forthcoming events and activities. Information about the Church's year came from a book called the Ordo, sent from Westminster to the clergy each year, or from a monthly magazine for bulletin producers. The 'thought for the day' material, stories and inspirational sections were taken from the Missal (Mass book) or from magazines. Requests for prayers came from various sources: knowledge about recent funerals in the parish or requests for a Mass for someone who had recently died, or whose anniversary it was; priests' anniversaries from the Ordo; 'the sick' from the priest's visiting list. The parish secretary had to fit all of this information into the bulletin in a digest form short enough to fit everything in, yet long enough to include all relevant information.

This process began when the parish priest sat down with the bulletin box and the parish diary, and dictated text in his own words. The secretary would then sit down at the computer and open up the previous week's bulletin in Microsoft Publisher. Elements that would run another week were kept in, and then the information from the priest's dictation was entered, adapted to written form as necessary.

Each week, decisions had to be made about what to include and what to leave out, based on various criteria. Interpersonal criteria were key. Information coming directly from one of the priests would go in automatically; information from parishioners was considered in relation to its urgency. General information from a non-parish source, such as background material on a saint's day, might be pushed out if space was tight. The key question deciding whether or not information would be included was whether there was some form of link with the parish. For example, reunions at Catholic schools in the area that parishioners might have attended were occasionally advertised, as a way of making links to people's history. The domain of the elements concerned also played a role in the selection criteria. The bulletin producer felt the 'Thought for the Day' and similar sections were particularly important, describing them as 'a form of adult religious education', designed to contribute to people's spiritual 
development. She therefore prioritised the inclusion of some elements of this kind each week, to balance out the more administrative functions.

In addition to balancing these selection criteria, the secretary considered each bulletin in relation to its position in a series over time. Announcements of events would be included several weeks or months early as 'warnings' for busy people who needed advance notice. They would run for two or three weeks, in case people missed an issue, and would then be taken out, to be put in again for a few weeks before the event took place. Pictures (generated by computer clip-art packages) were included not only for aesthetic reasons, 'to break up the text', but also for functional reasons, to link together over time sections which recurred every week, such as reminders of the sessions of the sacramental preparation courses which continued throughout the year. Cohesive links were thereby produced between different issues of the bulletin.

This description of the complexity of practices involved in the production of the bulletin demonstrates the creativity evident within what might appear a routinised production of similar texts week after week. Analysis of these practices highlights the range of creative responses to the particular exigencies of producing each issue, managing multiple resources and constraints. The parish secretary engaged in an ongoing process of selection from the information resources available to her, carefully crafting them into a form appropriate to the social and institutional constraints within which she was working, balancing interpersonal, temporal, institutional and stylistic factors. This involved a complex process of bringing together contributions from a wide variety of different sources, weighing up multiple considerations to choose what to include and to work out the best way of presenting the information. She collaborated with a range of actors in its production, drawing a myriad of different voices together in a single text that represented the multi-stranded 'voice of the parish'. Multiple and hybrid discourses - spiritual, bureaucratic, and administrative - were balanced in fulfilling the bulletin's many functions. This example underlines the creativity inherent in the production of a nonliterary form. It can be seen as an example of 'ubiquitous creativity', showing the range of creative practices inherent in the routine production of what at first sight might be thought of as a repetitive, highly structured text, produced by someone not traditionally positioned as a creative artist.

\section{Greativity and constraint: 'advertising literacy' in Namibia}

The next examples come from a larger ethnographic study of literacy practices in Namibia carried out in 1999 and 2000. The aim of this study was to explore the uses and meanings of literacy in people's everyday life and work. Fieldwork was carried out over a period of 10 months. The study used ethnographic methods, including participant observation, repeated 
informal conversations with informants and semi-structured interviews. Discourse analysis and visual analysis were drawn on as complementary tools, to explore the texts people produced and used as part of their daily lives.

At the time of the research, Namibia was in the middle of a process of rapid cultural, political and economic change. The end of South African rule and the abolition of apartheid in 1990 opened the country to foreign tourists and investors. Tourism was growing at a rapid pace and the country was gradually gaining a reputation as a place worth visiting. This provided new social opportunities for many Namibians. The growth of tourism, a trend that has carried on in more recent years, is particularly important for the majority of the black and coloured ${ }^{1}$ Namibians who - despite efforts by the government and support from foreign donors - experience high levels of unemployment and a low standard of living. In 1999 and 2000, when Papen conducted her research, local or 'community-based' tourism had seen a major boost, allowing small-scale enterprises, owned by black Namibians, to enter the tourism market.

Despite these developments, competition was fierce, and anybody trying to make money from tourism needed to be as inventive as they could when advertising their services. Advertising, in whatever form, is a playing field of creativity. In Namibia, where many producers cannot rely on high technologies or a wealth of materials, plain writing and perhaps some paint and drawing are often the only means of communication advertisers can afford. Many are also advertising in English, a language few people have been formally taught. In what follows, we will show the creativity that emerges from these social and economic conditions.

\section{Face-to-Face Tours: experiencing Katutura face-to-face}

The first example comes from research in Katutura, the former black township of Windhoek, the capital of Namibia (Papen 2007). There is a lot going on in Katutura, despite economic hardship and a general lack of resources. People build houses and shacks, they set up new businesses, form local associations and meet in bars (shebeens) or on the local markets. Business in Katutura is mostly small-scale and family-run. Women produce and sell goods, often as a secondary means to increase the family budget. Men offer their services as car mechanics or builders.

In the township, competition for tourist money is particularly high. Those working in the sector have to compete with the many companies that are located in Windhoek's city centre, much closer to the hotels and guest houses where the majority of the tourists stay. People have little money to invest into advertising, and few have any formal training in marketing and promotion. But this doesn't mean they don't advertise their goods. They have to. In such a context, creativity can be found in the choice and 
combination of materials people can get hold of and the opportunities they exploit to achieve what they desire to do.

In the summer of 2000, when Papen was in Namibia, she herself became such a resource to be drawn on. As part of her research, she worked closely with a group of tour guides who showed visitors around the township, its historical sites and contemporary life. Katutura Face-to-Face Tours was set up in 1999 by a group of young school leavers. The guides were supported by a local umbrella organisation for community-based tourism enterprises (CBTEs) and they were in possession of an advertising flyer, which they had produced with the help of a friend who was a journalist.

At the time of this research, they wished to update their flyer and to create additional promotional material. They wanted a flyer with photographs of a tourist being shown around the township. But they did not have the expertise or the means to produce such a document. They approached Papen to help them. Together they went around Katutura, staging photographs showing a European woman talking to locals and listening to a guide explaining the history of the township's cemetery. They then asked her to draft a text for their new flyer. The guides used these photos for a handmade board that they put together for a marketing stall at a large city fair.

This example demonstrates creativity in relation to the practices of making texts, by identifying materials, drawing on 'experts' and exploiting any means available in an environment scarce of resources and opportunities. It also demonstrates democratic creativity that occurs in unexpected places. Furthermore, Papen's example shows creativity emerging from collaboration, rather than being the product of an individual creative mind. It was the tour guides' idea to produce the photographs and they chose the places where the images were to be shot. But Papen and the group together decided what precise images to take. They also discussed the ideas for the flyer together, even if they then left it to Papen to produce the actual text ${ }^{2}$.

\section{Khowarib campsite}

The next example comes from Damaraland, the former homeland of the Damara people and nowadays an administrative region located in the eastern-central parts of Namibia. The Khowarib Camp (see Figure 2) is owned and run by a group of people from the Khowarib community, a small settlement in Damaraland. The campsite is situated close to the main road leading from Windhoek towards the north-west of the country. In theory, this makes Khowarib an ideal stopping point for anybody on their long and arduous way towards the Kaokoveld, one of Namibia's tourist attractions. But places like this suffer from the structural inequalities that 
characterise the Namibian tourism sector. Despite many measures to support community-based local (black) enterprises, the sector was and still is dominated by white and foreign-owned tourism companies. The majority of the tourists coming to Namibia prefer to stay in lodges owned by white Namibians or foreigners. Relatively few venture onto community-run campsites.

Places like Khowarib, which was founded by a local community with no prior experience in tourism, lack the resources for a professional marketing strategy which might help them attract more visitors to their site. But this does not mean that they fail to advertise their product or lack creativity in doing so. Figure 2 shows the signboard the owners of the Khowarib camp put up next to the road.

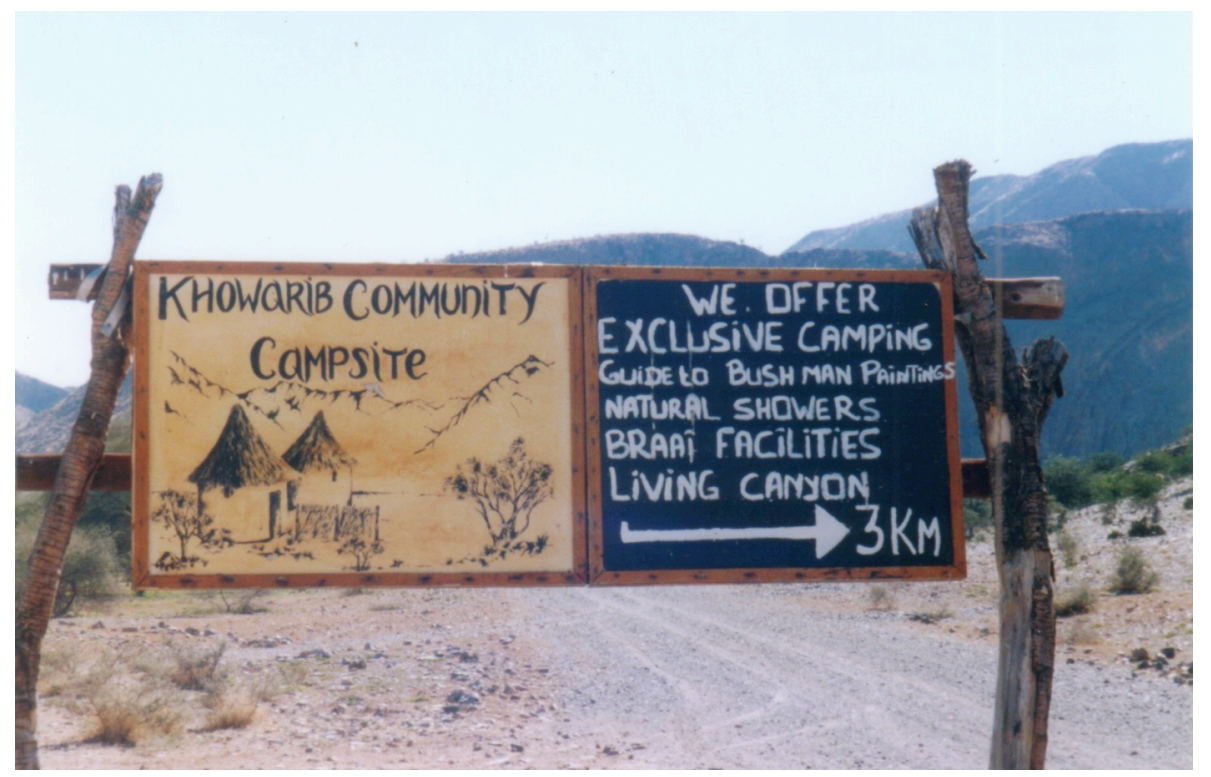

\section{Figure 2: Khowarib campsite}

The people of Khowarib told Papen that the making of the signboard had been a collaborative process, involving the Khowarib community and a business advisor from the same organisation that also supported Face-toFace Tours. Like the township guides, the people running the Khowarib campsites were newcomers to the tourism business and they, as many other community-based tourism enterprises, had only limited resources to draw on.

Looking closely at the images and accompanying text, we can see that this is semiotic work. Its goal is to create images (representations, both 
verbal and visual) of the advertised product that respond to the 'tourist gaze' (Urry 2002): their wishes and preferences, needs, desires and dreams.

Khowarib's signboard does a very good job at responding to the typical European or North-American tourist's dreams. Most tourists on their way to the wilderness of the Kaokoveld come to the country because of their interest in its natural environment. They would be likely to have a keen interest in local culture and to be happy to support the local economy. But, as thrilled as they would be to know that the campsite was largely built of natural materials, they would also be relieved to discover that the site provides the modern luxury of running water.

Its text is complemented by a drawing. The stereotypical representation of African huts continues with the same themes and metaphors set out in the writing. Jewitt and Oyama (2001) have pointed out that hand-drawn and photographic images are assessed by their viewers in different ways. The latter are judged by their reality value, the former appeal through their assumed authenticity. The images of the huts respond to the tourists' search for an 'authentic' African experience. The creativity of the signboard lies in the combination of textual and visual elements, a form of multimodality that was achieved without any high-tech equipment, cleverly exploiting the tourists' wishes and needs. The camp workers had drawn on their existing resources - their ability to draw - to construct a text that appeals to tourists by virtue of its hand-drawn quality.

\section{Greativity and literacy in Namibia: Concluding thoughts}

The signs presented above are examples of creative texts produced by people with little formal education and prior experience in marketing and design. Nevertheless, the texts produced are examples of the kind of everyday creativity that can be identified and appreciated by taking an ethnographic approach. In order to fully appreciate what is creative about these texts, we need to understand the ethnographic context out of which they were born. People in Namibia (and elsewhere) who experience rapid and drastic social and economic change need to adapt quickly to new linguistic contexts. Creativity is inherent in the exploration of often scarce available resources, and it involves the combination of new and old practices and text or image types. The writers of the Khowarib sign appropriated new discourses (of tourism) and relied on 'old' skills (drawing) to produce a creative sign. The tour guides appropriated the expertise and willingness to help of a foreign researcher who happened to be in the area to produce texts in new discourses of tourism that they were learning to draw on. In both cases, creativity was collaborative and democratic, drawing on the resources and abilities of different people with different backgrounds and experience. 


\section{Conclusion}

In this paper, we have looked at creativity in everyday, mundane contexts, and under conditions that are not usually seen as being conducive to creativity. Our examples show that once you look beyond the texts themselves, and examine the practices involved in producing and using them, the creativity that emerges from the opportunities and constraints inherent in different social, institutional and economic contexts becomes clear.

Analysis of the production practices of a parish bulletin showed the parish secretary skilfully and creatively negotiating a range of criteria and constraints of different kinds in producing, selecting and arranging the texts that became the parish newsletter. Examination of tourist advertising texts in Namibia has highlighted the creativity inherent in their production. What people like the owners of the Khowarib camp and the tour guides did, was to make creative use of the resources available in the context they lived in, despite their economic marginalization and the limited experience with tourism and advertising. In engaging in these processes of selection and recombination, the parish secretary, the guides from Face-to-Face Tours and the owners of the Khowarib camp can all be described, using LeviStrauss' term, as 'bricoleurs'.

Furthermore, these examples demonstrate the collaborative nature of creativity, showing that text making more often than not relies on a creative combination of contributions from more than one person. This idea is rarely highlighted in discussions of 'conventional', artistic creativity. It is however a common theme in more recent research on digital literacies (see for example Lankshear and Knobel 2006, 2007, Merchant 2001, 2005). Researchers who have looked at new forms of electronic reading and writing emphasize that creativity on the internet is often the result of a collaborative product. Our examples show that creativity and collaboration are also common features of more mundane and less technologically sophisticated forms of text-making.

More generally, the examples we have presented show, as Kress argues, that creative intellectual and semiotic work is part and parcel of people's everyday activities of communication and sense making, even where the texts they produce and use are not characterised by the sorts of language features that foreground Jakobson's poetic function. An ethnographic approach, which focuses on what people actually do with texts, how they use and produce texts in particular social and cultural contexts, brings to bear a perspective which complements other, more textbased approaches to understanding linguistic creativity. By seeing creativity in relation to its social context, we can, as Banaji and Burn suggest, 
understand and value creativity in people's literacy practices as an ubiquitous characteristic of communication.

\section{Acknowledgements}

Karin Tusting would like to express her appreciation to those many members of the parish who assisted with her research, and in particular to the parish secretary at the time, who was unfailingly supportive of the project and gave up her own time to assist in producing this analysis. Her research was supported by the Economic and Social Research Council.

Uta Papen would like to thank the members of the community-based tourism enterprises who shared her experiences with her. Her research was supported by a King's College London Association (KCLA) research studentship and the University of London's Central Research Fund. She is grateful to both institutions for their support. We would both like to thank David Barton, Joan Swann and Janet Maybin and anonymous reviewers for comments on earlier drafts of this paper.

\section{Endnotes}

1. We use the terms black, coloured and white without racist intention.

Black or black people refers to people of indigenous African origin.

Whites are people of European descent, although many of them were born in Africa. Coloured refers to people of mixed ancestry.

2. The intention had been that Papen would discuss her draft text with the group and then revise it following their feedback. However, in the end the idea never went beyond the first draft, because the local NGO supporting the guides prepared a new brochure including pages on all the CBTEs associated with them. There was no need and no financial support for an additional, separate flyer.

\section{References}

Banaji, S and Burn, A (2007) Creativity through a Rhetorical Lens: Implications for schooling, literacy and media education, Literacy, vol 41, no 2, pp 62-70.

Barton, David (2007) Literacy: An introduction to the ecology of written language, Blackwell Publishing Ltd, Oxford, 2nd edition.

Barton, David and Hamilton, Mary (1998) Local Literacies: Reading and Writing in One Community, Routledge, London and New York.

Barton, David and Hamilton, Mary (2000) 'Literacy practices' in Barton, D, Hamilton, M, Ivanič, R, eds, Situated Literacies, Routledge, London and New York, pp 7-15.

Carter, Ron (2004) Language and Creativity: The art of common talk, Routledge, London and New York. 
Cook, Guy (2000) Language Play, Language Learning, Oxford, Oxford University Press.

Craft, Anne (2001) An Analysis of Research and Literature on Creativity in Education, Qualifications and Curriculum Authority, London, retrieved 12 June 2007 from http://www.ncaction.org.uk/creativity/creativity_report.pdf.

Derrida, Jacques (1978) Structure, Sign and Play in the Discourse of the Human Sciences, Writing and Difference (278-294), trans. A. Bass, Routledge, London, retrieved 12 June 2007 from http://www.hydra.umn.edu/derrida/sign-play.html.

Hamilton, M. (1999) Ethnography for Classrooms: Constructing a reflective curriculum for literacy, Pedagogy, Culture and Society, vol 7, no 3, pp 429-444.

Jakobsen, R (1960) Closing Statement: Linguistics and poetics, in Sebeok, TA, ed, Style in Language, MIT Press, Cambridge, MA, pp 350-77.

Jewitt, Carey and Oyama, Rumiko (2001) Visual Meaning: A social semiotic approach, in Van Leeuwen, Theo and Jewitt, Carey, ed, Handbook of Visual Analysis, Sage, London, pp 134-157.

Lankshear, Colin and Knobel, Michelle (2006) New Literacies: Everyday practices and classroom learning, Open University Press, Buckingham.

Lankshear, Colin and Knobel, Michel, ed, (2007) A New Literacy Studies Sampler, Peter Lang. New York.

Levi-Strauss, Colin (1972) The Savage Mind, Weidenfeld and Nicolsen, London, translated from French.

Kress, Gunther (2003) Literacy in the New Media Age, Routledge, London and New York.

Maybin, Janet and Swann, Joan (eds) (2007) Language and Creativity in Social Context, special issue of Applied Linguistics, vol 28, no 4.

Merchant, Guy (2001) Teenagers in Cyberspace - An investigation of language use and language change in internet chatrooms, fournal of Research in Reading, vol 24, no 3, pp 293-306.

Merchant, Guy (2005) Digikids: Cool dudes and the new writing, E-learning, vol 2, no 1, pp 50-60.

Pahl, Kate (2007) Creativity in Events and Practices: A lens for understanding children's multimodal texts, Literacy, vol 41, no 2, pp 86-92.

Papen, Uta (2005) Adult Literacy as Social Practice: More than skills, Routledge, London and New York.

Papen, Uta (2007) Literacy and Globalisation: Reading and writing in times of social and cultural change, Routledge, London and New York.

Papen, Uta and Tusting, Karin (2006) Everyday Literacies: Collaboration, context and creativity, in Swann, Joan and Maybin, Janet, ed, The Art of English: Everyday creativity, Palgrave Macmillan Basingstoke, pp 312-350. 
Robins, Steven (1996) Cultural Brokers and Bricoleurs of Modern and Traditional Literacies: Land struggles in Namaqualand's coloured reserves, in Prinsloo, Mastin and Breier, Mignonne, eds, The Social Uses of Literacy, John Benjamins, Amsterdam, pp 123-141.

Street, Brian V (1984) Literacy in Theory and Practice, Cambridge University Press, Cambridge.

Street, Brian V (1993) Cross-Cultural Approaches to Literacy, Cambridge University Press, Cambridge.

Street, Brian V, ed (2001) Introduction, in Literacy and Development, Routledge, London, pp 21-27.

Tusting, Karin (2000a) Written Intertextuality and the Construction of Catholic Identity in a Parish Community: An ethnographic study, $\mathrm{PhD}$ thesis, Lancaster University.

Tusting, Karin (2000b) The New Literacy Studies and Time: An exploration, in Barton, D, Hamilton, M and Ivanič, R, ed, Situated Literacies: Reading and Writing in Context, London and New York: Routledge, pp 35-54.

Tusting, Karin and Barton, David (2005) Community-based Local Literacies Research, in Beach, R, Green, J, Kamil, M and Shanahan, T, ed, Multidisciplinary Perspectives on Literacy Research, Cresskill, New Jersey, Hampton Press Inc, pp 243-263.

Urry, John (2002) The Tourist Gaze: Leisure and travel in contemporary societies, Sage, London, 2nd edition. 
